Jud, G. D. and Daniel T. Winkler. "The Dynamics of Metropolitan Housing Prices," Journal of Real Estate Research, vol. 23, no. 1-2, 2002, pp. 29-45.

Made available courtesy of American Real Estate Society (ARES).

\title{
The Dynamics of Metropolitan Housing Prices
}

Authors

Abstract

\section{G. Donald Jud and Daniel T. Winkler}

This article is the winner of the Innovative Thinking "Thinking Out of the Box" manuscript prize (sponsored by the Homer Hoyt Advanced Studies Institute) presented at the 2001 American Real Estate Society Annual Meeting.

This study examines the dynamics of real housing price appreciation in 130 metropolitan areas across the United States. The study finds that real housing price appreciation is strongly influenced by the growth of population and real changes in income, construction costs and interest rates. The study also finds that stock market appreciation imparts a strong current and lagged wealth effect on housing prices. Housing appreciation rates also are found to vary across areas because of locationspecific fixed-effects; these fixed effects represent the residuals of housing price appreciation attributable to location. The magnitudes of the fixed-effects in particular cities are positively correlated with restrictive growth management policies and limitations on land availability.

\section{Introduction}

The factors that influence changes in housing prices are of interest to urban planners, developers, real estate professionals and financial executives as well as most American households. According to a 1998 Federal Reserve survey (Kennickell, Starr-McCluer and Surette, 2000), 66.2\% of households in the United States are homeowners, and housing investment amounts to $33 \%$ of household net worth. Over the past two decades, stock market appreciation has markedly increased the total wealth of U.S. households, but the linkage between housing prices and stock market wealth has not been explored. A number of studies have examined housing price change by metropolitan area, but few studies have been able to estimate the separate the effects of both demand- and supply-side variables.

This study examines the factors that influence real housing price changes in a sample of 130 metropolitan areas during the 1984 to 1998 period. In comparison to prior research, this research offers a much broader sample of MSAs over a longer time period. The study shows that real housing price appreciation is 
significantly related to changes in population and real changes in income, construction costs, stock price appreciation and after-tax interest rates. The analysis employs a fixed-effects model to control for MSA-specific factors that may influence appreciation rates in particular areas. The magnitudes of the fixedeffect coefficients are positively correlated with restrictive growth management policies and limitations on land availability.

\section{Past Studies of Housing Price Changes}

There have been a number of studies of housing prices and housing price changes. The focus here is on those studies that have examined housing price changes, rather than the level of prices. A review of early work in this area can be found in Bartik (1991, Chapter 5), who introduces a lagged adjustment model and provides additional empirical results. The studies reveal that housing appreciation is directly influenced by population and employment growth, although the estimated impacts of these factors vary widely. A study by Poterba (1991) examines the effects of population and income changes as well as the impacts of construction and after-tax user costs. He finds that income and construction costs are important in explaining housing cost changes, but his results provide no support for the role of demographic factors or after-tax user costs.

Abraham and Hendershott (1996) develop a model of housing price change that allows for a lagged adjustment process. Their model, which is estimated using the quality-adjusted Freddie Mac-Fannie Mae repeat transaction database for thirty metropolitan areas, reveals that that real housing price appreciation is directly related to increases in real construction costs, employment and real income. They find that appreciation rates are negatively related to rises in real interest rates.

The prolonged rise in stock prices over the past two decades has dramatically increased household wealth, and stock holdings have grown as a fraction of total household wealth, rising from 8.5\% in 1989 to $22.9 \%$ in 1998 (Kennickell, StarrMcCluer and Surette, 2000). ${ }^{1}$ Although the effect of wealth on consumption has been much debated (Ludvigson and Steindel, 1999; and Starr-McCluer, 1998), no work was found that focused specifically on the impact of wealth changes on housing expenditures or prices.

A number of economic models have examined the "wealth effect" on total consumer spending. Most of these models estimate that a one-dollar increase in stock market wealth raises consumer spending by three to seven cents per year (Starr-McCluer, 1998), but the magnitude of the effect remains a subject of debate and research. For example, a recent paper by Poterba (2000) suggests the wealth effect might be less than three cents per dollar, while work by Ludvigson and Steindel (1999) finds evidence that the effect of wealth on durable goods spending is larger and more long lasting than its effect on total spending. 
This study analyzes the determinants of real housing price change using a sample encompassing 130 metro areas from 1984 through 1998. The model introduces a wealth effect on housing prices, and an MSA fixed-effects model is utilized to account for changes in metropolitan-specific cost factors. The model is estimated with a maximum likelihood procedure that allows correction of the time-series, cross-sectional sample for heteroskedasticity and autocorrelation within metropolitan cross sections.

The sample data of housing prices are derived from recently available qualityadjusted housing price indexes reported by the Office of Federal Housing Enterprise Oversight (OFHEO). OHHEO's House Price Indexes are available at the MSA level. They track average house price changes in repeat sales or refinancings on the same single-family properties and are based on analysis of data obtained from over 11.9 million repeat transactions over the past twenty years (OFHEO, 1999).

\section{The Model and Empirical Specification}

The demand for housing in any metropolitan market $(i)$ at time $(t)$ is given by:

$$
Q_{i, t}^{D}=D\left(P_{i, t}, Y_{i, t}, W_{i, t}, I_{i, t}, P_{o p}, p_{i, t}, u_{i, t}\right)
$$

\section{Where:}

$$
\begin{aligned}
P_{i . t} & =\text { Real housing price; } \\
Y_{i . t} & =\text { Real income; } \\
W_{i . t} & =\text { Real wealth; } \\
I_{i . t} & =\text { Real after-tax mortgage interest rate; } \\
P o p_{i . t} & =\text { Population; and } \\
u_{i . t} & =\text { Random error term. }
\end{aligned}
$$

Similarly, market supply is defined as:

$$
Q_{i, t}^{S}=S\left(P_{i, t}, I_{i, t}, C_{i, t}, M_{i, t}, v_{i, t}\right)
$$

Where:

$P_{i . t}=$ Real housing price;

$I_{i . t}=$ Real after-tax mortgage interest rate;

$C_{i . t}=$ Real construction costs;

$M_{i, t}=$ MSA-specific cost factors; and

$v_{i, t}=\mathrm{A}$ random error term. 
All variables are defined in logarithms.

In equilibrium:

$$
Q_{i, t}^{D}=Q_{i, *}^{S}
$$

Substituting Equations (1) and (2) into Equation (3), produces the reduced form equation:

$$
P_{i, t}=f\left(Y_{i, t}, W_{i, t}, I_{i, t}, \operatorname{Pop}_{i, t}, C_{i, t}, M_{i, t}, z_{i, t}\right)
$$

All of the variable coefficients are assumed to be positive except for the coefficient on the real mortgage rate, where the sign is indeterminate. ${ }^{2}$

The percentage change in prices during any time period is measured by $\% \Delta P_{i, t}$, or $\left(P_{i, t}-P_{i, t-1}\right) / P_{i, t-1}$, and, assuming no lags in the adjustment process, is estimated by:

$$
\% \Delta P_{i, t}=f\left(\% \Delta Y_{i, t} \% \Delta W_{i, t} \% \Delta I_{i, t} \% \Delta \operatorname{Pop}_{i, t} \% \Delta M_{i, t}, e_{i, t}\right)
$$

Equation (5) is estimated using a pooled time-series cross-section model with MSA fixed effects. ${ }^{3}$ In place of $\% \Delta M_{i, r}$, which represents the percentage change in MSA-specific cost factors, a vector of MSA dummy variables (fixed effects) is utilized to capture the average percentage change in MSA-specific cost factors over the sample period.

All of the variables in Equation (5) reflect changes in real values; thus, in compiling sample date, all monetary values are deflated by a regional index of prices, in order to focus on changes in real values. The regional Consumer Price Indexes (CPI-U), compiled by the Bureau of Labor Statistics (BLS), are used to measure price level changes. Specific aggregate price indexes are available for twenty-four metropolitan areas. ${ }^{4}$ For those MSA's where the BLS does not produce a specific CPI-U, the CPI-U for the corresponding urban census region is used.

To test the appropriateness of the price deflation procedure, a restricted sample is formed using only the twenty-four MSAs for which the BLS has a metropolitan specific CPI-U. The model (Equation (5)) is estimated using the restricted sample, and the results are reported in the Appendix in Exhibits A.1-A.3. (The Appendix exhibits correspond with Exhibits 1-3.) Overall, the restricted-sample results accord completely with the findings obtained using the full sample of $130 \mathrm{MS}$ As. The results from the full sample are discussed in the following sections. 
The sample data covers 130 metropolitan markets with annual data for 1984-98. The real price variable $\left(P_{i, t}\right)$ is the quality-adjusted housing price index for metropolitan markets reported by the OFHEO and deflated by the regional price index. The real income variable $\left(Y_{i, t}\right)$ is the personal income per capita in real terms for the MSA. The real wealth variable $\left(W_{i, t}\right)$ is measured by the S\&P 500 stock index deflated by the regional cost index. The effects of real cost factors are measured in two ways. First the construction cost component of the producer price index deflated by the CPI-U is used to capture the effects of national changes in real construction costs. ${ }^{5}$ Second, factors specific to each MSA, other than real wage increases, are proxied by MSA-specific dummy variables. Increases in real wages are captured by the real income variable $\left(Y_{i, t}\right)$.

The real after-tax interest rate variable $\left(\boldsymbol{I}_{i, t}\right)_{1}$ the annual average real after-tax, effective rate on conventional loans closed. The after-tax mortgage rate is computed using the mean tax rate calculated from the personal income series as reported by the Bureau of Economic Analysis. ${ }^{6}$ The real rate is computed by subtracting the ex post inflation rate, as measured by the regional CPI-U's, from the after-tax mortgage rate. ${ }^{7}$ The real interest rate variable in Equation (5) is the percentage change in the real after-tax rate $\left(\% \Delta I_{i,}\right)$.

Population (Pop,,,) is the estimated total MSA population as reported by the Bureau of Economic Analysis in the personal income series.

In estimating Equation (5), MSA-specific autocorrelation is corrected by estimating separate AR terms for each MSA cross-section, allowing the AR terms to vary among the MSAs. ${ }^{8}$ Hereroskedasticity within MSA cross sections is corrected with a generalized least squares procedure for cross-section weighted regression. The White heteroskedasticity consistent covariance correction is also applied to adjust for non-constant variances across cross sections.

The possibility of lags in the housing market adjustment process was examined by including into Equation (5) the lagged values of independent variables. The only variables where significant lags were found were real stock prices and real construction costs. In the reported results, a lag is introduced into the model for the stock prices, allowing the real wealth effect to extend over more than one year. A real construction cost lag also is added to the model to capture the delayed effects of construction costs on existing house prices. ${ }^{9}$

\section{Empirical Results}

Exhibit 1 shows the estimates of Equation (5) with lagged changes in stock prices and construction costs. All of the coefficients are statistically significant and have the expected signs. The $R^{2}$ is $65 \%$ and the overall regression model is statistically significant. The Durbin-Watson statistic indicates most of the effects of autocorrelation have been removed. 
Exhibit 1 | Determinants of Housing Price Change

\begin{tabular}{lllr} 
Independent Variable & Coefficient & Std. Error & t-value \\
\hline$\% \Delta Y_{i, t}$ & 0.1679 & 0.0261 & 6.43 \\
$\% \Delta W_{i, t}$ & 0.0988 & 0.0047 & 21.00 \\
$\% \Delta W_{i, t-1}$ & 0.0628 & 0.0033 & 18.93 \\
$\% \Delta l_{i, t}$ & 0.0239 & 0.0018 & 13.01 \\
$\% \Delta$ Pop $_{i, t}$ & 1.0892 & 0.0973 & 11.19 \\
$\% \Delta C_{i, t-1}$ & 0.1216 & 0.0101 & 12.00 \\
$R^{2}$ & 0.65 & & \\
F-statistic & 9.77 & & \\
D.W. & 1.80 & & \\
\hline
\end{tabular}

Notes: MSA fixed effects are shown in Exhibit 2. $n=1,690$.

The estimated coefficients reveal that a $1 \%$ change in real per capita income is associated with a modest, but statistically significant, $0.17 \%$ change in real housing prices. A notable feature of the research relates to the effects of real wealth accumulation (or stock prices) on housing values. A 1\% change in stock prices is found to produce a $0.16 \%$ change in housing values after the full effect of the one-period lag is felt. These results suggest a significant real wealth effect operates in the existing housing market and that the lagged change in real wealth makes an important contribution to the total real wealth effect. ${ }^{10}$

The findings also indicate a $1 \%$ change in real, after-tax mortgage interest rates is associated with a $0.024 \%$ increase in real prices, and a $1 \%$ change in real construction costs raises housing values by $0.12 \%$ following a one-period lag.

Real housing values at the MSA level are found to be most responsive to changes in population. A $1 \%$ change in the rate of population growth raises communityhousing values by $1.09 \%$.

Exhibit 2 shows the MSA fixed effects for 130 MSAs with the coefficients ranked from lowest to highest. The dummy variable coefficients of only seven MSAs are positive, and none of these positive coefficients are statistically significant. This finding suggests that price appreciation in most all MSAs would have been less than the inflation rate, were it not for the influence of changes in population and real changes in income, construction costs, stock market valuation and mortgage interest rates. ${ }^{11}$ Among the 130 MSA dummy variable coefficients, sixty are statistically significant at the 5\% level or better and forty-seven are significant at the $1 \%$ level. ${ }^{12}$ 
Exhibit 2 | MSA Fixed Effects

\begin{tabular}{|c|c|c|c|c|c|}
\hline Fips Code & Metropolitan Area & State & Coefficient & Std. Error & t-value \\
\hline 74120 & Las Vegas* & $N V-A Z$ & -8.813 & 1.024 & -8.609 \\
\hline 75960 & Orlando* & $\mathrm{FL}$ & -6.205 & 1.222 & -5.078 \\
\hline 78960 & West Palm Beach-Boca Raton* & $\mathrm{FL}$ & -6.198 & 0.875 & -7.081 \\
\hline 72020 & Daytona Beach* & $\mathrm{FL}$ & -5.840 & 0.700 & -8.338 \\
\hline 72800 & Fort Worth-Arlington* & TX & -5.628 & 0.769 & -7.320 \\
\hline 71920 & Dallas* & TX & -5.559 & 0.526 & -10.576 \\
\hline 74900 & Melbourne-Titusville-Palm Bay* & $\mathrm{FL}$ & -5.489 & 1.316 & -4.169 \\
\hline 76200 & Phoenix-Mesa* & $A Z$ & -5.348 & 1.991 & -2.685 \\
\hline 76640 & Raleigh-Durham-Chapel Hill* & NC & -5.238 & 1.213 & -4.318 \\
\hline 70520 & Atlanta* & GA & -5.138 & 0.634 & -8.110 \\
\hline 76720 & Reno* & NV & -5.132 & 1.223 & -4.196 \\
\hline 78520 & Tucson* & $A Z$ & -4.900 & 1.191 & -4.113 \\
\hline 73360 & Houston* & TX & -4.479 & 0.729 & -6.144 \\
\hline 75720 & Norfolk-Virginia Beach* & VA-NC & -4.425 & 0.519 & -8.529 \\
\hline 78280 & $\begin{array}{l}\text { Tampa-St. Petersburg- } \\
\text { Clearwater* }\end{array}$ & $\mathrm{FL}$ & -4.399 & 0.513 & -8.581 \\
\hline 72840 & Fresno* & $C A$ & -4.352 & 1.551 & -2.807 \\
\hline 70680 & Bakersfield* & $C A$ & -4.350 & 1.752 & -2.482 \\
\hline 72680 & Fort Lauderdale* & $\mathrm{FL}$ & -4.341 & 0.731 & -5.941 \\
\hline 77510 & Sarasota-Bradenton* & $\mathrm{FL}$ & -4.306 & 0.691 & -6.227 \\
\hline 78780 & Visalia-Tulare-Porterville* & $C A$ & -4.208 & 1.719 & -2.447 \\
\hline 77240 & San Antonio* & $T X$ & -4.001 & 0.895 & -4.470 \\
\hline 71880 & Corpus Christi* & TX & -3.970 & 0.778 & -5.102 \\
\hline 70200 & Albuquerque & NM & -3.943 & 2.817 & -1.400 \\
\hline 79160 & Wilmington-Newark & DE-MD & -3.943 & 2.903 & -1.358 \\
\hline 76780 & Riverside-San Bernardino* & CA & -3.894 & 1.718 & -2.267 \\
\hline 70640 & Austin-San Marcos* & TX & -3.888 & 1.666 & -2.334 \\
\hline 76760 & Richmond-Petersburg* & VA & -3.805 & 0.284 & -13.407 \\
\hline 79040 & Wichita* & KS & -3.801 & 1.520 & -2.500 \\
\hline 71520 & Charlotte-Gastonia-Rock Hill* & NC-SC & -3.779 & 0.670 & -5.639 \\
\hline 75015 & Middlesex-Somerset-Hunterdon & NJ & -3.742 & 4.257 & -0.879 \\
\hline 73120 & Greensboro/Winston-Salem* & NC & -3.713 & 0.394 & -9.414 \\
\hline 74280 & Lexington* & KY & -3.694 & 1.252 & -2.950 \\
\hline 72120 & Des Moines* & IA & -3.673 & 1.631 & -2.252 \\
\hline 74920 & Memphis* & TN-AR-MS & -3.625 & 0.560 & -6.478 \\
\hline 78440 & Topeka* & KS & -3.620 & 0.867 & -4.173 \\
\hline
\end{tabular}


Exhibit 2 | (continued)

MSA Fixed Effects

\begin{tabular}{|c|c|c|c|c|c|}
\hline Fips Code & Metropolitan Area & State & Coefficient & Std. Error & t-value \\
\hline 74680 & Macon* & GA & -3.595 & 0.593 & -6.058 \\
\hline 73200 & Hamilton-Middletown* & $\mathrm{OH}$ & -3.587 & 0.387 & -9.266 \\
\hline 72760 & Fort Wayne* & $\mathbb{I N}$ & -3.511 & 0.717 & -4.895 \\
\hline 73760 & Kansas City* & MO-KS & -3.508 & 1.018 & -3.446 \\
\hline 77490 & Santa Fe & NM & -3.471 & 1.986 & -1.748 \\
\hline 75360 & Nashville & TN & -3.425 & 2.130 & -1.608 \\
\hline 78560 & Tulsa* & OK & -3.398 & 0.958 & -3.546 \\
\hline 76690 & Redding & CA & -3.350 & 1.961 & -1.708 \\
\hline 71150 & Bremerton & WA & -3.228 & 2.613 & -1.235 \\
\hline 76680 & Reading* & PA & -3.224 & 1.187 & -2.716 \\
\hline 74940 & Merced & CA & -3.203 & 1.676 & -1.911 \\
\hline 75170 & Modesto* & $C A$ & -3.167 & 1.554 & -2.038 \\
\hline 78840 & Washington & DC-MD-VA-WV & -3.154 & 2.488 & -1.268 \\
\hline 77040 & St. Louis* & MO-IL & -3.095 & 0.677 & -4.574 \\
\hline 71123 & Boston-Worcester-Lowell & MA-NH & -3.093 & 2.245 & -1.378 \\
\hline 70875 & Bergen-Passaic & NJ & -3.057 & 4.006 & -0.763 \\
\hline 75120 & Minneapolis-St. Paul* & MN-WI & -3.015 & 0.680 & -4.436 \\
\hline 74400 & Little Rock-North Little Rock & AR & -3.010 & 2.375 & -1.267 \\
\hline 74000 & Lancaster* & PA & -2.961 & 0.896 & -3.307 \\
\hline 78160 & Syracuse* & NY & -2.948 & 1.384 & -2.130 \\
\hline 75800 & Odessa-Midland* & TX & -2.881 & 0.980 & -2.939 \\
\hline 73480 & Indianapolis* & IN & -2.867 & 0.284 & -10.111 \\
\hline 71720 & Colorado Springs & $\mathrm{CO}$ & -2.866 & 2.056 & -1.394 \\
\hline 72670 & Fort Collins-Loveland & $\mathrm{CO}$ & -2.860 & 2.844 & -1.006 \\
\hline 73160 & $\begin{array}{l}\text { Greenville-Spartanburg- } \\
\text { Anderson* }\end{array}$ & SC & -2.824 & 0.859 & -3.289 \\
\hline 74360 & Lincoln* & NE & -2.767 & 1.183 & -2.340 \\
\hline 73240 & Harrisburg-Lebanon-Carlisle* & PA & -2.746 & 0.235 & -11.710 \\
\hline 70840 & Beaumont-Port Arthur* & TX & -2.723 & 0.621 & -4.382 \\
\hline 76880 & Rockford* & IL & -2.708 & 0.806 & -3.360 \\
\hline 75640 & Newark & NJ & -2.623 & 4.134 & -0.634 \\
\hline 78120 & Stockton-Lodi & CA & -2.602 & 1.613 & -1.612 \\
\hline 78720 & Vallejo-Fairfield-Napa & CA & -2.590 & 1.359 & -1.906 \\
\hline 72080 & Denver & $\mathrm{CO}$ & -2.549 & 1.451 & -1.757 \\
\hline 70760 & Baton Rouge* & LA & -2.502 & 0.902 & -2.774 \\
\hline
\end{tabular}


Exhibit 2 | (continued)

MSA Fixed Effects

\begin{tabular}{|c|c|c|c|c|c|}
\hline Fips Code & Metropolitan Area & State & Coefficient & Std. Error & t-value \\
\hline 75000 & Miami* $^{*}$ & $\mathrm{FL}$ & -2.404 & 0.557 & -4.317 \\
\hline 70720 & Baltimore & $M D$ & -2.400 & 1.560 & -1.539 \\
\hline 75190 & Monmouth-Ocean & NJ & -2.347 & 4.278 & -0.549 \\
\hline 74720 & Madison & WI & -2.313 & 1.226 & -1.887 \\
\hline 78480 & Trenton & NJ & -2.306 & 3.946 & -0.584 \\
\hline 76920 & Sacramento & CA & -2.297 & 1.869 & -1.229 \\
\hline 75380 & Nassau-Suffolk & NY & -2.260 & 4.102 & -0.551 \\
\hline 73000 & $\begin{array}{l}\text { Grand Rapids-Muskegon- } \\
\text { Holland* }\end{array}$ & $\mathrm{Ml}$ & -2.197 & 0.543 & -4.043 \\
\hline 75920 & Omaha & NE-IA & -2.192 & 2.419 & -0.906 \\
\hline 71000 & Birmingham* & AL & -2.147 & 0.640 & -3.352 \\
\hline 75880 & Oklahoma City* & OK & -2.136 & 0.926 & -2.307 \\
\hline 77840 & Spokane & WA & -2.131 & 2.369 & -0.900 \\
\hline 77320 & San Diego & $\mathrm{CA}$ & -2.113 & 1.749 & -1.208 \\
\hline 70860 & Bellingham & WA & -2.091 & 3.287 & -0.636 \\
\hline 71640 & Cincinnati* & $\mathrm{OH}-\mathrm{KY}-\mathrm{IN}$ & -2.049 & 0.250 & -8.194 \\
\hline 76160 & Philadelphia & PA-NJ & -2.010 & 3.205 & -0.627 \\
\hline 71125 & Boulder-Longmont & $\mathrm{CO}$ & -2.009 & 2.663 & -0.754 \\
\hline 77500 & Santa Rosa & $C A$ & -1.915 & 2.957 & -0.648 \\
\hline 70240 & Allentown-Bethlehem-Easton & PA & -1.859 & 3.433 & -0.541 \\
\hline 77600 & Seattle-Bellevue-Everett & WA & -1.859 & 2.018 & -0.921 \\
\hline 76483 & Providence-Warwick-Pawtucket & RI & -1.846 & 4.967 & -0.372 \\
\hline 78200 & Tacoma & WA & -1.738 & 2.304 & -0.755 \\
\hline 74040 & Lansing-East Lansing* & $\mathrm{Ml}$ & -1.735 & 0.751 & -2.310 \\
\hline 77120 & Salinas & CA & -1.627 & 2.154 & -0.755 \\
\hline 75560 & New Orleans & LA & -1.590 & 1.261 & -1.261 \\
\hline 75600 & New York & NY & -1.574 & 5.092 & -0.309 \\
\hline 71600 & Chicago & IL & -1.544 & 1.612 & -0.958 \\
\hline 72000 & Dayton-Springfield* & $\mathrm{OH}$ & -1.354 & 0.303 & -4.466 \\
\hline 75775 & Oakland & CA & -1.299 & 2.207 & -0.588 \\
\hline 76740 & Richland-Kennewick-Pasco & WA & -1.276 & 2.188 & -0.583 \\
\hline 71280 & Buffalo-Niagara Falls & NY & -1.251 & 1.482 & -0.844 \\
\hline 74520 & Louisville* & $K Y-I N$ & -1.201 & 0.486 & -2.470 \\
\hline 70380 & Anchorage & AK & -1.187 & 1.182 & -1.004 \\
\hline 70440 & Ann Arbor & MI & -1.157 & 0.661 & -1.750 \\
\hline
\end{tabular}


Exhibit 2 | (continued)

MSA Fixed Effects

\begin{tabular}{|c|c|c|c|c|c|}
\hline Fips Code & Metropolitan Area & State & Coefficient & Std. Error & t-value \\
\hline 78400 & Toledo & $\mathrm{OH}$ & -1.131 & 0.614 & -1.842 \\
\hline 75080 & Milwaukee-Waukesha & WI & -1.098 & 0.729 & -1.507 \\
\hline 72960 & Gary & $\mathbb{N}$ & -1.013 & 1.164 & -0.870 \\
\hline 76280 & Pittsburgh & PA & -1.000 & 0.527 & -1.897 \\
\hline 76120 & Peoria-Pekin & U & -0.975 & 0.895 & -1.090 \\
\hline 77080 & Salem & OR & -0.925 & 2.143 & -0.432 \\
\hline 70080 & Akron* & $\mathrm{OH}$ & -0.803 & 0.317 & -2.529 \\
\hline 75483 & New Haven-Bridgprt & $\mathrm{CT}$ & -0.781 & 4.616 & -0.169 \\
\hline 77460 & San Luis Obispo-Paso Robles & CA & -0.718 & 2.997 & -0.239 \\
\hline 76440 & Portland-Vancouver & OR-WA & -0.675 & 1.811 & -0.373 \\
\hline 73283 & Hartford & $\mathrm{CT}$ & -0.626 & 3.462 & -0.181 \\
\hline 73720 & Kalamazoo-Baitle Creek & $\mathrm{MI}$ & -0.610 & 0.903 & -0.676 \\
\hline 71680 & Cleveland-Lorain-Elyria & $\mathrm{OH}$ & -0.595 & 0.436 & -1.363 \\
\hline 77480 & $\begin{array}{l}\text { Santa Barbara-Santa Maria- } \\
\text { Lompoc }\end{array}$ & $\mathrm{CA}$ & -0.586 & 1.831 & -0.320 \\
\hline 75945 & Orange County & CA & -0.546 & 2.480 & -0.220 \\
\hline 77160 & Salt Lake City-Ogden & UT & -0.541 & 4.322 & -0.125 \\
\hline 71320 & Canton-Massillon & $\mathrm{OH}$ & -0.451 & 1.199 & -0.376 \\
\hline 78735 & Ventura & CA & -0.430 & 2.375 & -0.181 \\
\hline 76960 & Saginaw-Bay City-Midland & Ml & -0.332 & 0.992 & -0.334 \\
\hline 72640 & Flint & Ml & -0.043 & 1.217 & -0.035 \\
\hline 72160 & Detroit & MI & 0.285 & 0.787 & 0.362 \\
\hline 77485 & Santa Cruz-Watsonville & CA & 0.597 & 3.014 & 0.198 \\
\hline 72400 & Eugene-Springfield & OR & 0.631 & 0.978 & 0.645 \\
\hline 77400 & San Jose & $\mathrm{CA}$ & 0.799 & 2.870 & 0.279 \\
\hline 73320 & Honolulu & $\mathrm{HI}$ & 0.825 & 4.425 & 0.186 \\
\hline 74480 & Los Angeles-Long Beach & CA & 1.290 & 2.591 & 0.498 \\
\hline 77360 & San Francisco & CA & 1.704 & 3.822 & 0.446 \\
\hline
\end{tabular}

Note: *MSA with statistically significant coefficients with a $t$-value of 2.0 or larger. 
The model appears to be well specified with changes in real income, population, real wealth, real construction costs and real interest rates accounting for most of the variation in real price changes among MSAs, leaving comparatively little variation to be explained by the dummy variables (MSA-specific growth factors). Over a fourteen-year time period, it is reassuring that real price changes in most MSAs can be explained by changes in the real income, population, real interest rates, real wealth and real cost variables. Nonetheless, for the sixty-nine MSAs with statistically significant dummy variables, local factors also contribute to an understanding of real price changes. This issue is examined in detail in the following section.

The coefficients in Exhibit 2 show the average annual percentage increase in real existing housing values attributable to location, after controlling for real changes in income, population, wealth, construction costs, and interest rates. For example, holding the effects of all other independent variables constant, real housing prices in San Francisco are estimated to have risen 1.7\% annually, while prices in Las Vegas are estimated to have declined 8.8\%. A perusal of Exhibit 2 indicates that cities with the largest coefficients are located on the West coast and Hawaii and in the North and East. The lowest rates of price appreciation appear in cities in the South and Southwest where land availability is high and growth restrictions appear to be low.

\section{Comparisons with Prior Studies}

Four prior studies (Segal and Srinivasan, 1985; Rose, 1989; Linneman, Summers, Brooks and Buist, 1990; and Malpezzi, 1996) have constructed growth restriction indexes. The indexes developed by Segal and Srinivasan, Linneman, et al. and Malpezzi were concerned with local regulatory restrictions on growth. Rose focused on land availability.

Exhibit 3 shows the correlations between the estimated MSA fixed effects (Exhibit 2) and the indexes developed in other studies. Two sets of correlations are shown. The first row of Exhibit 3 presents the unadjusted correlations. The second row lists the correlations obtained using the standard errors of the estimated MSA fixed effects as weights in calculating the correlation coefficients.

Since the data used in past studies were collected at different time periods and the time periods do not correspond completely with the dates of the data used in this study, perfect correlations cannot be expected. Nevertheless, Exhibit 3 indicates that the estimated MSA fixed effects are significantly correlated with growth restriction indexes developed in prior studies. The negative correlation with Rose's (1989) index indicates that the fixed-effects measure is negatively related to land availability. The positive correlations with the other three indexes suggest that local regulatory restrictions impede housing growth, causing a larger appreciation in local housing prices. The same pattern of correlation is found using 
Exhibit 3 | Correlations with Prior Studies of Growth Restrictions

\begin{tabular}{lllll} 
& $\begin{array}{l}\text { Linneman, Summers, } \\
\text { Brooks and Buist }\end{array}$ & Malpezzi & Rose & $\begin{array}{l}\text { Segal and } \\
\text { Srinivasan }\end{array}$ \\
\hline Unadjusted correlation & $0.340^{* *}$ & 0.118 & $-0.307^{*}$ & $0.248^{*}$ \\
Adjusted correlation & $0.482^{* * *}$ & $0.367^{* * *}$ & $-0.390^{* *}$ & $0.271^{*}$ \\
$N$ & 48 & 113 & 37 & 47 \\
\hline
\end{tabular}

* Significant at the .10 level or better.

${ }^{* *}$ Significant at the .05 level or better.

${ }^{* * *}$ Significant at the .01 level or better.

the results of the restricted sample of twenty-four MSAs, which is shown in Exhibit A.3.

The correlation results shown in Exhibit 3 (Exhibit A.3) indicate that the fixed effect coefficients reported in Exhibit 2 (Exhibit A.2) may be interpreted properly as measures of the magnitude of restrictions on housing growth attributable to specific metropolitan areas. Thus, the empirical model employed in this study provides a useful approach for measuring the effects of restrictive growth management policies and limited land availability.

\section{Conclusion}

This study examines housing price growth dynamics in metropolitan areas across the U.S. Real housing price appreciation is found to be strongly influenced by the real growth of population, income, construction costs and interest rates. The real stock market appreciation is also found to impart a strong current and lagged wealth effect on the growth of real housing prices. Lastly, appreciation rates are found to vary across areas because of location-specific fixed-effects, although most of the variation in appreciation stems from differences in the rates of growth of real income and population.

The MSA fixed effects in this study represent the residuals of housing price appreciation attributable to location. The magnitudes of the fixed effects in particular cities are positively correlated with restrictive growth management policies and limitations on land availability. Therefore, the empirical model in this study provides a useful method of identifying the effects of restrictive growth policies and limited land availability on the pace of housing price changes in specific MSAs. 
\begin{tabular}{l} 
The Dynamics of Metropolitan Housing Prices \\
41 \\
\hline
\end{tabular}

Appendix

Exhibit A.1 | Restricted-Sample Results

\begin{tabular}{|lllr|}
\hline Independent Variable & Coefficient & Std. Error & t-value \\
\hline$\% \Delta Y_{i, t}$ & 0.2053 & 0.0686 & 2.99 \\
$\% \Delta W_{i, t}$ & 0.1161 & 0.0111 & 10.50 \\
$\% \Delta W_{i, t-1}$ & 0.0743 & 0.0082 & 9.07 \\
$\% \Delta I_{i, t}$ & 0.0196 & 0.0037 & 5.25 \\
$\% \Delta P_{o p_{i, t}}$ & 0.9411 & 0.2901 & 3.24 \\
$\% \Delta C_{i, t-1}$ & 0.1398 & 0.0240 & 5.83 \\
$R^{2}$ & 0.67 & & \\
$F$-statistic & 9.81 & & \\
D.W. & & & \\
\hline Notes: MSA fixed effects are shown in Exhibit A.2. $n=318$. & \\
\hline
\end{tabular}


Exhibit A.2 | Restricted Sample: MSA Fixed Effects

\begin{tabular}{|c|c|c|c|c|c|}
\hline Fips Code & Metropolitan Area & ST & Coefficient & Std. Error & $t$-value \\
\hline 71920 & Dallas* & TX & -5.775 & 0.855 & -6.755 \\
\hline 70520 & Attanta* & GA & -5.273 & 1.077 & -4.896 \\
\hline 73360 & Houston* & TX & -4.812 & 0.873 & -5.509 \\
\hline 73760 & Kansas City* & MO-KS & -3.869 & 1.139 & -3.398 \\
\hline 77040 & St. Louis* & MO-IL & -3.595 & 0.784 & -4.584 \\
\hline 71123 & Boston-Worcester-Lowell & MA-NH & -3.472 & 2.224 & -1.561 \\
\hline 75120 & Minneapolis-St. Paul* & $M N-W I$ & -3.334 & 0.828 & -4.027 \\
\hline 72080 & Denver & $\mathrm{CO}$ & -2.826 & 1.830 & -1.544 \\
\hline 75000 & Miami* $^{*}$ & FL. & -2.682 & 0.757 & -3.542 \\
\hline 76160 & Philadelphia & PA-NJ & -2.483 & 3.147 & -0.789 \\
\hline 71640 & Cincinnati* & $\mathrm{OH}-\mathrm{KY}-\mathrm{IN}$ & -2.462 & 0.460 & -5.356 \\
\hline 77320 & San Diego & CA & -2.270 & 1.893 & -1.200 \\
\hline 77600 & Seattle-Bellevue-Everett & WA & -2.065 & 2.229 & -0.927 \\
\hline 75600 & New York & NY & -2.023 & 4.929 & -0.410 \\
\hline 71600 & Chicago & IL & -1.946 & 1.483 & -1.312 \\
\hline 76280 & Pittsburgh* & PA & -1.585 & 0.635 & -2.494 \\
\hline 70380 & Anchorage & AK & -1.557 & 1.145 & -1.360 \\
\hline 75080 & Milwaukee-Waukesha & WI & -1.544 & 0.969 & -1.593 \\
\hline 71680 & Cleveland-Lorain-Elyria & $\mathrm{OH}$ & -1.120 & 0.588 & -1.905 \\
\hline 76440 & Portland-Vancouver & OR-WA & -0.719 & 2.229 & -0.323 \\
\hline 72160 & Detroit & MI & -0.241 & 0.714 & -0.338 \\
\hline 73320 & Honolulu & $\mathrm{HI}$ & 0.473 & 4.479 & 0.106 \\
\hline 74480 & Los Angeles-Long Beach & CA & 0.931 & 2.595 & 0.359 \\
\hline 77360 & San Francisco & CA & 1.175 & 3.685 & 0.319 \\
\hline
\end{tabular}


Exhibit A.3 | Restricted Sample: Correlations with Prior Studies of Growth Restrictions

\begin{tabular}{|c|c|c|c|c|}
\hline & $\begin{array}{l}\text { Linneman, Summers, } \\
\text { Brooks and Buist }\end{array}$ & Malpezzi & Rose & $\begin{array}{l}\text { Segal and } \\
\text { Srinivasan }\end{array}$ \\
\hline Unadjusted correlation & $0.509^{* *}$ & $0.577^{* * *}$ & $-0.489^{* *}$ & $0.532^{* *}$ \\
\hline Adjusted correlation & $0.611^{* * *}$ & $0.691^{* * *}$ & $-0.475^{* *}$ & $0.498^{* *}$ \\
\hline$N$ & 21 & 22 & 21 & 20 \\
\hline
\end{tabular}

\section{Endnotes}

1 Ludvigson and Steindel (1999) report that a one-point move in the Dow Jones Industrial average changes household wealth by $\$ 1$ billion to $\$ 2$ billion.

2 The sign on the real mortgage interest rate variable is indeterminant because when interest rates rise, the housing supply curve shifts upward to the left, while the housing demand curve shifts downward to the left. The net impact on housing prices and the real interest rate coefficient depends on the relative shifts of the demand and supply curves. Although it would be possible to try variations of current and lagged interest rates, theory does not provide a model for choosing a particular interest rate specification. The efficient markets literature suggests, however, that historical interest rate changes should not be related to current and future interest rate changes. Also the expected impact of interest rate changes on housing prices is expected to be minimal compared with other variables such as population and real income changes.

3 The variables for real wealth, real after-tax mortgage rate, and real construction costs are estimated for MSAs using national data The use of national data permits the variation in real housing prices because of local growth restrictions to be captured by the MSA-specific dummy variables.

4 The twenty-four areas are: Anchorage, Atlanta, Boston, Chicago, Cincinnati, Cleveland, Dallas, Denver, Detroit, Honolulu, Houston, Kansas City, Los Angeles, Miami, Milwaukee, Minneapolis, New York, Philadelphia, Pittsburgh, Portland, St. Louis, San Diego, San Francisco and Seattle.

5 Producer Price Index series number WPUSOP1220.

6 The tax rates are calculated using personal income and personal disposable income; however, the personal disposable income series is not available for specific MSAs. Although the impact of using a national tax rate is likely to be small, there could be a shift in some MSA dummy variables.

7 Ideally, the ex ante rather than the ex post inflation rate might be subtracted to calculate the real interest rate, but ex ante inflation rates are only available nationally rather than regionally. Also, because this study encompasses a fifteen-year time period, the differences between ex anti and ex post rates should not be large, since over long time periods ex ante and ex post inflation rates should be the same.

\begin{tabular}{l|l|ll} 
JRER & VOI. 23 & Nos. $1 / 2-2002$ \\
\hline
\end{tabular}


8 Estimations were undertaken using the Eviews 3.1 software package from Quantitative Micro Software.

9 The results for the construction cost variable indicate that only the lagged construction cost variable is statistically significant, while the current construction cost variable is not. This result is not surprising based on the time delay in construction and the expectation that cost impacts to the existing home markets would rise only after new home prices adjust to higher construction costs. Also, contracts often "lock in" new house prices during construction, with higher costs being absorbed by the contractors thereby reducing their profits. Only the lagged construction cost variable coefficient is reported.

$10 \mathrm{It}$ is likely that the local impact of stock prices may vary by metropolitan area, because of differences in stock holdings and the distribution of wealth. To test for this possibility, a separate slopes model was constructed with an interaction effect of the MSA dummy variables and the real wealth variable, that is, adding 130 slope coefficients to the model. At that point, the national real wealth variable is removed from the model to avoid a singular data matrix. A separate slopes model for the lagged real wealth variable was not possible because the model becomes singular, so the lagged national real wealth variable is retained in the model together with the separate slopes (MSA wealth specific) variables. A Chow test is conducted by comparing this specification with the regression shown in Exhibits 1 and 2. The F-value of 1.5 is statistically significant, but the R2 increases only about 1\%. The coefficients on the stock-market variables shown in Exhibit 1 reflect an average real wealth effect calculated across all 130 areas. When the MSA dummy variables shown in Exhibit 2 were compared with the set obtained using the separate slopes model, the correlation was found to be quite close. The Spearman rank coefficient is 0.86 . This result suggests that while there is some change in the rankings of MSA price growth as measured by the dummy variables, most MSAs rank very similarly under either model. The same procedure was repeated with the twenty-four MSAs shown in Exhibits A1-A3, the Spearman rank correlation is 0.775 , largely the same as with the 130 MSA sample. 11

11 From 1985 through 1998, the average real growth in residential housing prices was only $0.9 \%$ annually, not controlling for other influences including changes in income, population, stock market wealth, construction costs and interest rates.

12 An F-test of the joint significance of the MSA coefficients revealed a calculated Fvalue of 1.10 , which is not statistically significant at the $5 \%$ level. The test involves a comparison of the error sum of squares between the "restricted" and "unrestricted" regressions. Pindyck and Rubinfeld (1981: 124) detail the statistical test.

\section{References}

Abraham, J. M. and P. H. Hendershott, Bubbles in Metropolitan Housing Markets, Journal of Housing Research, 1996, 7:2, 191-208.

Bartik, T. J., Who Benefits from State and Local Economic Development Policies?, Kalamazoo, MI: W. E. Upjohn Institute, 1991.

Kennickell, A. B., M. Starr-McCluer and B. J. Surette, Recent Changes in U.S. Family Finances: Results from the 1998 Survey of Consumer Finances, Federal Reserve Bulletin, 2000, 86:1, 1-29.

Linneman, P. A., A. Summers, N. Brooks and H. Buist, The State of Local Growth Management, Working Paper No. 81, Philadelphia, PA: The Wharton School, 1990. 
Ludvigson, S. and C. Steindel, How Important is the Stock Market Effect on Consumption?, Federal Reserve Bank of New York Economic Policy Review, 1999, 5:2, 29-52.

Malpezzi, S., Housing Prices, Externalities, and Regulation in U.S. Metropolitan Areas, Journal of Housing Research, 1996, 7:2, 209-42.

Office of Federal Housing Enterprise Oversight (OFHEO), House Price Index, Third quarter, 1999.

Poterba, J. M., House Price Dynamics: The Role of Tax Policy and Demography, Brookings Papers on Economic Activity, 1991, 2, 143-99.

., Stock Market Wealth and Consumption, The Journal of Economic Perspectives, 2000, 14:2, 99-118.

Rose, L. A., Topographical Constraints and Urban Land Supply Indexes, Journal of Urban Economics, 1989, 26:3, 335-47.

Pindyck, R. S. and D. L. Rubinfeld, Econometric Model and Economic Forecasts, Second edition, New York, NY: McGraw-Hill, 1981.

Segal, D. and P. Srinivasan, The Impact of Suburban Growth Restrictions on U.S. Housing Price Inflation, 1975-78, Urban Geography, 1985, 6:1, 14-26.

Starr-McCluer, M., Stock Market Wealth and Consumer Spending, Federal Reserve Board of Governors, Working paper, April, 1998.

The authors thank the Joseph M. Bryan School of Business and Economics for a research grant funding this study. The authors are indebted to Stephen Malpezzi for generously sharing his metropolitan area database.

G. Donald Jud, University of North Carolina-Greensboro, Greensboro, NC 27402-

6165 or juddon@uncg.edu.

Daniel T Winkler, University of North Carolina-Greensboro, Greensboro, NC 27402-

6165 or dt_winkler@uncg.edu. 